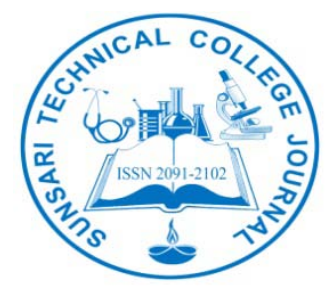

\title{
SEROPREVALENCE OF HEPATITIS B AND HEPATITIS C AMONG BLOOD DONORS AT DHARAN, SUNSARI, NEPAL
}

\author{
Sabina Rai ${ }^{1}$, Pranita Dongol ${ }^{{ }^{*}}$, Hemanta Khanal ${ }^{2}$ \\ ${ }^{1}$ Department of Microbiology, Sunsari Technical College, Dharan, Nepal \\ ${ }^{2}$ Department of Microbiology, Central Campus of Technology, Hattisar, Dharan \\ Corresponding author email: pranitadongol@yahoo.com \\ Received: 16.04.2015; Revised and Accepted- 9.06.2015
}

DOI: http://dx.doi.org/10.3126/stcj.v2i1.14791

\begin{abstract}
Hepatitis B and Hepatitis C are the chronic viral infection that might be transmitted by blood transfusion. Nepal is known to have lowest seroprevalence in Asia. The main objective of the present study is to find out the prevalence of hepatitis B and Hepatitis C and their co-infection among blood donors during study period from March to August 2014. This was a cross sectional study among volunteer blood donors in Dharan who had donated the Blood. A total of 4930 donated blood samples were collected and screened for hepatitis B and hepatitis C by using a rapid enzyme immunoassay (EIA) technique. Among 4930 blood samples under study, the overall seroprevalence of hepatitis B were $0.22 \%$ (11 out of 4930 ) and hepatitis C were 0.39\% (19 out of 4930) (P value $=0.01)$ and the prevalence being lower in females than males for both cases. Hepatitis B were more in age group of $21-30(0.4 \%)$ but hepatitis C in age group of 31-40 (0.5\%). Hepatitis B and C are potential threats to be transmitted from unscreened blood.
\end{abstract}

Key Words:Seroprevalence, hepatitis B, hepatitis C, blood donors

\section{INTRODUCTION}

Hepatitis B is a viral diseasecaused by hepatitis B. Hepatitis B virus (HBV) and hepatitis $\mathrm{C}$ virus are two important chronic hepatic infections. ${ }^{(1,2)}$ An acute or chronic viral infection is confirmed by presence of hepatitis B surface antigen (HBsAg) and antibodies to hepatitis C core antigen. ${ }^{(3,}{ }^{4)}$ In blood transfusion there is risk of hepatitis B and hepatitis C transmission due to window period of viral infection and precincts in diagnosis procedure and techniques. ${ }^{(5-7)} \mathrm{WHO}$ estimates more than 240 million people have chronic liver infections and more than 780000 people die every year due to the acute or chronic infections of hepatitis $\mathrm{B} .{ }^{(8)}$ The transmission of hepatitis B by blood transfusion in Nepal is a risk because of diagnosis by a one-step enzyme immunoassay. Use of ELISA technique increases the diagnosis of early infections. ${ }^{(3)}$

From various studies from 1990 to 2009 in Nepal seroprevalence of hepatitis $\mathrm{B}$ and $\mathrm{C}$ is found to be below $1.5 \%{ }^{(9-14)}$ The people with both hepatitis B and hepatitis $\mathrm{C}$ are called HBV/HCV co-infections. Hepatitis B and C co-infection causes a serious mortality, morbidity and financial burden. ${ }^{(15)}$

The results of co-infection study in Nepal show various rate ranging from $0.71 \% .{ }^{(16)}$ The main aim of this study is to find out the seroprevalence of hepatitis B and C and their co-infections among blood donors of Sunsari District Nepal.

\section{MATERIALS AND METHODS}

This was a cross-sectional study conducted in Sunsari District of Nepal in Nepal over a six months period from March to August 2014. The eligible blood donors selected according to criteria of standard operating procedure of Nepal Red Cross Society blood transfusion service. A total of 4930 donated bloods including mobile camps and bloods collected in the blood transfusion service were included in the study. Screening of hepatitis B and Hepatitis $C$ were performed by enzyme immunoassay based test kits hepacard and HCV TRI-DOT rapid (J. Mitra and Co, New Delhi, India) by taking $5 \mathrm{ml}$ of blood from a blood pouch. A 
positive serum was tested repeatedly by same test kits. The statistical analysis was done using SPSS ver 16 .

\section{RESULTS}

In Dharan, a total of 4930 blood samples were tested in whom $81.8 \%$ were male and $18.2 \%$ were female. Among 4950 blood donors 11 (0.22\%) donors were positive to HBV and 19 (0.39\%) were positive to HCV. The HBV seroprevalence in male donors male seroprevalence were $0.18 \%(9 / 4032)$ and $0.04 \%(2 / 898)$ at p value $<0.05$.

Table 1: Gender wise seroprevalence of $\mathrm{HBV}$ and $\mathrm{HCV}$

\begin{tabular}{|l|l|l|l|l|l|l|}
\hline \multirow{2}{*}{ Infection } & \multicolumn{2}{|l|}{ Male } & Female & Overall \\
\cline { 2 - 6 } & Positive & $\begin{array}{l}\% \\
\text { Prevalen } \\
\text { ce }\end{array}$ & Positive & \% Prevalence & P Value \\
\hline HBV & $9 / 4032$ & 0.22 & $2 / 898$ & 0.22 & 0.22 & $<0.05$ \\
\hline HCV & $16 / 4032$ & 0.4 & $3 / 898$ & 0.33 & 0.39 & \\
\hline
\end{tabular}

The overall highest seroprevalence of HBV (0.4\%) in age group of 21-30 years followed by age group of 18-20 years (0.17\%) and 3140years $(0.06 \%)$ and age group above 41 years were found to be negative to HBV. In case of hepatitis C the age groups of $31-40$ years were highest with seroprevalence of $0.5 \%$ followed by $21-30$ years $(0.43 \%)$ and below $20(0.34 \%)$. The age above 41 years were negative to hepatitis C. Among all the blood donors 1/4930 (0.02\%) was positive to HBV and HCV.

Table 2: Age wise and gender wise seroprevalence of $\mathrm{HBV}$ and $\mathrm{HCV}$

\begin{tabular}{|c|c|c|c|c|c|c|}
\hline Age Group & Gender & $\begin{array}{l}\text { Overall Sample } \\
\text { Tested }\end{array}$ & $\begin{array}{l}\text { Reactive to HBV } \\
\text { (\%) }\end{array}$ & Reactive to HCV (\%) & $\begin{array}{l}\text { Co-infection of } \mathrm{HBV} \\
\text { and } \mathrm{HCV}\end{array}$ & P-value \\
\hline \multirow[t]{2}{*}{$18-20$} & M & 463 & - & $1(0.22)$ & - & \multirow{11}{*}{$<0.05$} \\
\hline & $\mathrm{F}$ & 127 & $1(0.79)$ & $1(0.79)$ & - & \\
\hline \multirow[t]{2}{*}{$21-30$} & M & 1725 & $8(0.47)$ & $8(0.47)$ & $1(0.05)$ & \\
\hline & $\mathrm{F}$ & 381 & $1(0.26)$ & $1(0.26)$ & - & \\
\hline \multirow[t]{2}{*}{$31-40$} & M & 1291 & $1(0.88)$ & $7(0.54)$ & - & \\
\hline & $\mathrm{F}$ & 296 & - & $1(0.34)$ & - & \\
\hline \multirow[t]{2}{*}{$41-50$} & $\mathrm{M}$ & 465 & - & - & - & \\
\hline & $\mathrm{F}$ & 83 & - & - & - & \\
\hline \multirow[t]{2}{*}{$51-60$} & M & 88 & - & - & - & \\
\hline & $\mathrm{F}$ & 11 & - & - & - & \\
\hline Total & & 4930 & $11(0.22)$ & $19(0.39)$ & $1(0.02)$ & \\
\hline
\end{tabular}

\section{DISCUSSIONS AND CONCLUSIONS}

The present study was carried out on Nepal Red Cross Society, Dharan branch for the detection of seroprevalence of hepatitis B, Hepatitis C and their co-infection. Out of 4930 blood samples were screened, $11(0.22 \%)$ and $(0.39 \%)$ were positive to hepatitis $\mathrm{B}$ and Hepatitis $\mathrm{C}$ respectively. The highest positivity of both hepatitis $\mathrm{B}$ and $\mathrm{C}$ were observed in male with age group of 21-30 followed by 31-40 with the similar rate of seroprevalence of $0.47 \%$.
The seroprevalence of hepatitis B were highest in Banke (1.2\%) followed by Morang (0.87\%) and Kaski $(0.35 \%)$ and HCV was highest in the Morang $(0.26 \%)$ then in Kanski $(0.16 \%)$ and Banke $(0.11 \%)$ district of Nepal on a research conducted by Tiwari et al., in 2010. The nationwide prevalence of HCV was $0.54 \%$ and in central blood transfusion service in Kathmandu was $0.7 \%$ on previous study. ${ }^{(17,18)}$ The study shows hepatitis B and $\mathrm{C}$ seroprevalence are higher among males with rate of $0.18 \%$ and $0.40 \%$ than in females with rate of $0.04 \%$ and $0.33 \%$ 
and this study is similar in results with the other researches performed previously. $(14,19,20)$

Previous study reported that the higher HBsAg carrier rate varied from 0 to $1.9 \%$ in Europe and America and 8 to $15 \%$ in Asian countries. ${ }^{(21-24)}$ Blood donation is vital but there is a higher risk of blood borne transfusion Transmissible Infection in donated blood due to the window period of viral infections and it also increases the risk in disease transmission organ donation. ${ }^{(25,26)}$ Reduction of seroprevalence on blood donors can be reduced by strict donor selection criteria, education to donor and blood donation by regular volunteer donors only. Similarly proper counseling of infected donors might establish useful decrease the seroprevalence of transfusion transmissible infections among blood donors. The present study showed that the seroprevalence of HCV was higher than HBV. So, donor awareness program is recommended to reduce the risk of infections due to blood transfusion.

\section{ACKNOWLEDGEMENT}

The authors would like to acknowledge to all the members of Nepal Red Cross Society, Dharan branch, Nepal and all the members of Department of Microbiology, Sunsari Technical College Dharan.

\section{REFERENCES}

1. Liang TJ. Hepatitis B: the virus and disease. Hepat. 2009;49(S5):13-21.http://dx.doi.org/10.1002/hep.22881 PMid:19399811 PMCid:PMC2809

2. Lok ASF, McMahon BJ. Chronic hepatitis B: update of recommendations. Hepat. 2004;39(3):857-61.

http://dx.doi.org/10.1002/hep.20110

PMid:14999707

3. Krajden M, McNabb G, Petric M. The laboratory diagnosis of hepatitis B virus. The Can J of Inf Dis\& Med Microb. 2005;16(2):65. PMid:18159530

4. Lauer GM, Walker BD. Hepatitis C virus infection. New Eng J of Med. 2001;345(1):41-52. http://dx.doi.org/10.1056/NEJM200107053450107PMid:11439 948

5. Mahoney FJ. Update on diagnosis, management, and prevention of hepatitis B virus infection. ClinMicrob Reviews. 1999;12(2):351-66.

PMid:10194463 PMCid:PMC88921

6. Richter SS. Laboratory assays for diagnosis and management of hepatitis $C$ virus infection. Journal of Clinical Microbiology. 2003;41(1):530.

http://dx.doi.org/10.1128/JCM.41.1.530.2003

PMCid:PMC149651

7. Krajden M. Hepatitis C virus diagnosis and testing. Canadian Journal of Public Health/Revue Canadienne de SantePublique. 2000:S34-S9.

8. World Health O. Hepatitis B. Fact sheet N 204, updated July 2014.
9. Khanal H, Bhatta DR, Tiwari BR, Joshi DR. Seroprevalence of Hepatitis B among blood donors in Jhapa, Nepal. STCJ 2012; 1(1):33-7.

10. Singh R. Prevalence of hepatitis-C in blood donors. A pilot study. J of Nep Med Assoc. 1992;30(101):1-6.

11. Shrestha SM, Subedi NB, Shrestha S, Maharjan KG, Tsuda F, Okamoto H. Epidemiology of hepatitis $C$ virus infection in Nepal. Tropical gastroenterology: Official J of the Digest Dis Foundation. 1997;19(3):102-4.

12. Shrestha IL. Seroprevalence of antibodies to hepatitis C virus among injecting drug users from Kathmandu. Kathmandu Univ Med J. 2003; 1:101-3.

13. Shrestha B. Serological surveillance of Anti HCW Antibody among Nepalese males. J of Nep Healt Res Council. 2008.

14. Shrestha AC, Ghimire P, Tiwari BR, Rajkarnikar M. Transfusion-transmissible infections among blood donors in Kathmandu, Nepal. The J of Infect in Dev Countries. 2009;3(10):794-7.http://dx.doi.org/10.3855/jidc.311

15. Kleinman SH, Kuhns MC, Todd DS, Glynn SA, McNamara A, DiMarco A, et al. Frequency of HBV DNA detection in US blood donors testing positive for the presence of antiâ€?HBc: implications for transfusion transmission and donor screening. Transf. 2003;43(6):696-704.http://dx.doi.org/10.1046/j.15372995.2003.00391.x

16. Shrestha AC, Ghimire P, Tiwari BR, Rajkarnikar M. Coinfection rate of HIV, HBV and Syphilis among HCV seropositive identified blood donors in Kathmandu, Nepal. Infect Eco \&Epidemio. 2012;2:793 - 7.

17. Tiwari BR, Ghimire P, Kandel SR, Rajkarnikar M. Seroprevalence of HBV and HCV in blood donors: A study from regional blood transfusion services of Nepal. Asian J of transfSci.4(2):91.

18. Karki S, Ghimire P, Tiwari BR, Maharjan A, Rajkarnikar $\mathrm{M}$. Trends in hepatitis B and hepatitis C seroprevalence among Nepalese blood donors. JpnJ Infect Dis. 2008;61(4):324-6. PMid:18653982

19. Easow JM, Shankar PR, Tuladhar R, Singh YI.

Seroepidemiology Of Hepatitis B Virus Infection Diagnosed At A Teaching Hospital In Western Nepal: A Prospective Study. J ClinDiag Res.4:3100-89.

20. Gyawali K, Devkota B, Acharya B. A study on correlation between between hepatitis $\mathrm{B}$ surface antigen and liver function test and the possible factors responsible for hepatitis B among the patients attending tribhuvan University Teaching Hospital: Nepal Health Research Council; 2001. A Technical Report

21. Chattoraj A, Behl R, Kataria VK. Infectious disease markers in blood donors. Medical J Armed Forces India. 2008;64(1):33-5.http://dx.doi.org/10.1016/S03771237(08)80142-6

22. Manzoor I, Hashmi N, Daud S, Ajmal S, Fatima H, Rasheed $\mathrm{Z}$, et al. Seroprevalence of transfusion transmissible infections (TTIS) in blood donors. Biomedica. 2009;25(2):154-8. 
23. Bhawani Y, Rao PR, Sudhakar V. Seroprevalence of transfusion transmissible infections among blood donors in a tertiary care hospital of Andhra Pradesh. Biol Med. 2(4):45-8.

24. Bhattacharaya P, Chandra PK, Datta S, Banerjee A, Chakrarborthu S, Rajendran K. A significant increase in the HBV, HCV, HIV and the Syphilis infections among the blood donors in West Bengal, eastern India 2004-2005. W J of Gastroenter. 2007;19(27):3730-33.

25. Mikolasevic I, Sladoje-Martinovic B, Milic S, Lukenda V,
Zupan Z, Stiimac D, et al. Evaluation of viral hepatitis in solid organ transplantation. ActaMedica Croatica.68(2):151-

9.PMid:26012153

26. Bish EK, Ragavan PK, Bish DR, Slonim AD, Stramer SL. A probabilistic method for the estimation of residual risk in donated blood. Biostat. 2014;15(4):620 35.

http://dx.doi.org/10.1093/biostatistics/kxu017PMid:24784858

Cite this article as: Rai S.,Dangol P, Khanal H. Seroprevalence of Hepatitis B and Hepatitis C among blood donors at Dharan, Sunsari, Nepal. STCJ 2015;2(1):13-16. 